\title{
Výchova ke zdraví v učebnicích 1. stupně ZŠ: výsledky analýzy didaktického aparátu učebnic prvouky/prírodovědy ${ }^{1}$
}

\author{
Markéta Hrozová \\ Masarykova univerzita, Pedagogická fakulta, Katedra psychologie
}

Redakci zasláno 19. 10. 2014 / upravená verze obdržena 28. 1. 2015 / k uveřejnění přijato 9. 2. 2015

\begin{abstract}
Abstrakt: Cílem empirické studie je prezentace výsledků obsahové analýzy didaktického aparátu učebnic a cvičebnic školního vzdělávacího předmětu prvouka/př́rodověda určených pro žáky 1 . stupně základních škol z hlediska jejich zaměření na výchovu ke zdraví. V první části studie prezentujeme teoretický základ našeho výzkumu, který spočíval ve vymezení analytických kategorií vyplývajících z holistického pojetí zdraví. $V$ druhé části představujeme cíle a metody výzkumu, výzkumný vzorek sestávající z pěti současných ucelených učebnicových řad učebnic prvouky/ př́rodovědy (38 učebnic/cvičebnic; 3136 zkoumaných jednotek, tedy otázek, námětů a úkolů zařazených do učebnic) platných pro 1 . stupeň základního vzdělávání. Třetí část je věnována výsledkům analýzy, která poukázala na významné rozdíly v prezentaci učiva v oblasti výchova ke zdraví. Z výsledků vyplývá nereflektování holistického pojetí zdraví v jeho plném rozsahu, majoritní zastoupení biologického kontextu zdraví ve zkoumaných učebnicích. Holistické pojetí zdraví nejvíce reflektují učebnice druhých ročníků. Dále poukazujeme na významné rozdíly ve strukturaci učiva v rámci jednotlivých učebnicových řad (absence tematiky zdraví ve většině zkoumaných učebnic 4. ročníků) a nestabilitu v distribuci tematických celků zkoumaného vzorku učebnic. $\mathrm{V}$ závěru studie (čtvrtá a pátá část) jsou diskutovány výsledky, možnosti a limity studie a představujeme eventuality navazujícího výzkumného šetření.
\end{abstract}

Klíčová slova: výchova ke zdraví, primární vzdělávání, učebnice, holistické pojetí zdraví, didaktický aparát učebnic, obsahová analýza

Zdraví není v současném celosvětovém pojetí (WHO, 1948) pouze obrazem tělesných funkcí těla, nejedná se o „pouhou“ nepř́tomnost nemoci. Je chápáno holisticky, jako bio-psycho-sociální pohoda determinovaná mnoha faktory nejrůznějšího charakteru. Čím více je tematika zdraví podrobena studiu,

1 Studie vznikla za podpory projektu Kurikulum základní školy: metodologické př́stupy a empirická zjištění - KUME 2014 (MUNI/A/0813/2013). 
tím více determinant nacházíme (srov. Holčík, 2010; Kebza, 2005). Ve vzdělávacích dokumentech se výchova ke zdraví, ${ }^{2}$ jako vzdělávací obor, etablovala v roce 1995, a to v rámci Standardu základního vzdělávání, ze kterého následně obsahově vycházely další vzdělávací dokumenty. V současnosti je sice výchova ke zdraví obsahově vymezena $\mathrm{v}$ Rámcovém vzdělávacím programu pro základní vzdělávání (RVP ZV, 2007, s aktualizací z roku 2013), avšak díky vymezenému obsahu vzdělávání v oblasti zdraví v kurikulu vyvstává na povrch zásadní otázka: Dle jakého pojetí zdraví a jakým způsobem je obsah vzdělávání v oblasti výchova ke zdraví strukturován a následně předkládán žákovi prostřednictvím učiva $v$ učebnicích prvouky/přírodovědy primární školy?

Učebnice jsou jedním z didaktických prostředků sloužících k postupnému osvojování plné zdravotní gramotnosti chápané „nejen jako schopnost osvojit si potřebné znalosti, dovednosti a návyky, ale i formovat postoje, názory a potřeby tak, aby gramotnost jedince aktivně přispěla ke zdraví jedince ve významu základní výbavy pro život" (Holčík, 2010, s. 147). Učebnice by tak prostřednictvím svého obsahového vymezení měly žáky vést $\mathrm{k}$ osvojování zdravotních dovedností pro život, ke schopnostem vidět v nich smysl a prospěch pro své zdraví. Jsou „nejdůležitějším zdrojem poznávání žákü“ (Skalková, 2007, s. 106) a plní významnou didaktickou funkci. Výzkum učebnic se obecně zaměřuje na různé oblasti - od výzkumů realizovaných v rámci kurikula a analýzy reálné výuky přes hodnocení vlastností výuky po výzkumy škol reflektující potřeby škol a učitelů. Výzkum učebnic plně reflektující prezentaci výchovy ke zdraví v učebnicích prvouky a přírodovědy na 1. stupni ZŠ doposud nebyl v českém prostředí realizován (Mužíková, 2010, s. 10).

2 Termín výchova ke zdraví ve studii užíváme nikoliv ve smyslu samostatného vzdělávacího oboru (tj. kurikulum výchovy ke zdraví), který je platný pro 2. stupeň základních škol (dle RVP ZV, 2013), ale jako pojem představující obecnou podstatu vzdělávání v oblasti zdraví (prezentovanou $\mathrm{v}$ učebnicích prvouky/přírodovědy pro 1.-5. ročník ZŠ). V širším pojetí chápeme termín výchova ke zdraví jako úsilí o podporu zdraví v procesu celoživotního vzdělávání (součástí výchovy a vzdělávání) s akcentem na postupné osvojování a zvyšování zdravotní gramotnosti jedince. Na 1. stupni ZŠ se výchova ke zdraví realizuje především prostřednictvím vyučovacích předmětů (s následným využitím učebnic prvouky/ přírodovědy, které jsou výzkumným předmětem studie) prvouka (1. období), přírodověda (2. období) / vzdělávací oblasti Člověk a jeho svět, tematického okruhu Člověk a jeho zdraví, vzdělávacího oboru Tělesná výchova (vzdělávací oblast Člověk a zdraví), průřezových témat (např. osobnostně-sociální výchova, environmentální výchova) integrovaných do jednotlivých předmětů, doplňkových vzdělávacích oborů (etická výchova) nebo v rámci dalších programů podporujících zdraví. 
Prezentace tematiky zdraví $\mathrm{v}$ učebnicích primární školy závisí na více faktorech. Za všechny zmiňme oblast oborových didaktik školních předmětů souvisejících se zdravotní tematikou, kurikulární dokumenty školní i státní úrovně a v neposlední řadě i roli tvůrců jednotlivých učebnicových řad. Stejně jako kurikulární dokumenty školní úrovně mohou být variovány v závislosti na jednotlivých základních školách, tak strukturace obsahu vzdělávání se může výrazně lišit $\mathrm{v}$ rámci pojetí jednotlivých nakladatelství učebnic. Zjišt'ovali jsme, jaký obsah vzdělávání $\mathrm{v}$ této oblasti se, v návaznosti na současné kurikulární požadavky, transformoval do edukačních materiálů. Předpokládáme, že obsah vzdělávání v oblasti výchova ke zdraví je v rámci jednotlivých učebnicových řad pocházejících z různých nakladatelství prezentován různě, ale s jistými společnými znaky.

\section{Vymezení zkoumané problematiky}

Předmětem naší analýzy byl didaktický aparát učebnic ${ }^{3}$ prvouky/přírodovědy, přičemž jsme hledali odpověd' na otázku, jak je v jeho rámci oblast výchovy ke zdraví zastoupená. Při vlastní analýze jsme kladli důraz na vztah mezi obsahem oboru, kurikulárním obsahem (prezentovaný RVP ZV) a učivem prezentovaným $\mathrm{v}$ učebnicích, nebot' pro realizaci našeho šetření byl „didaktický systém oboru důležitou částí, jelikož v okruhu těchto problémů dochází $\mathrm{k}$ vlastní transformaci oboru do jeho didaktického systému“ (Brockmeyerová-Fenclová, Čapek, \& Kotásek, 2000, s. 33). Vzhledem k multidisciplinární povaze vzdělávací oblasti výchova ke zdraví byl holistický model zdraví využit jako teoretický základ pro tvorbu výzkumného nástroje. Holistické pojetí zdraví považujeme za př́nosné vzhledem k jeho celostnímu pohledu na zdraví jedince. Díky němu bylo umožněno teoreticky pojmout a následně kategorizovat všechny obsahové aspekty vzdělávací oblasti výchova ke zdraví.

\subsection{Holistický model zdraví jako inspirativní zdroj využitý k tvorbě kategoriálního systému}

Na zdraví jedince je potřeba nahlížet (a následně i možno v edukačním prostředí jej ovlivňovat) jedině komplexně, a to v aspektech „bio-psychických, socio-kulturních a spirituálních“ (srov. Liba, 2008, s. 57). Holistický

Didaktickým aparátem učebnic myslíme otázky, úkoly, náměty k činnosti a k zamyšlení, které jsou uvedeny před, za a mezi probíranými texty (tématy), vztahující se k aktuálně probíranému celku i v rámci opakování k tématu, ročníku (celému i předchozímu), obsahově spjaté s tematikou zdraví (Průcha, 1998, s. 17). 
model zdraví je (vycházíme z prací Jensena, 1997; Kirstena, Van der Walta a Viljoena, 2009 a Pauluse, 2005) navíc k výše uvedeným aspektům dle Liby (2008) doplněn o ekologický kontext zdraví. Ten poukazuje na ekologické aspekty (životní prostředí, ve kterém žijeme; chování jedince přetvářejícího přírodu, majícího významný vliv na zdraví člověka atd.), které determinují naše zdraví. Holistické pojetí zdraví a jeho naplnění v učebnicích 1. stupně ZŠ je předmětem výzkumného šetření. V následujícím textu se věnujeme holistickým modelům zdraví (Jensen, 1997; Kirsten et al., 2009; Paulus, 2005), které tvořily teoretický základ výzkumného šetření.

Jensenův celostní (holistický) model zdraví (1997) vystihuje přechod od biomedicínského pojetí zdraví k pojetí demokratickému. ${ }^{4}$ Této transformaci je přizpůsoben obsah vzdělávání tak, aby vyučování v oblasti zdraví podporovalo celistvé vnímání zdraví jedince. Jensen považuje biomedicínské a holistické paradigma ve výchově ke zdraví za dva základní možné přístupy ke zdraví, které jsou uplatňovány v obsahu vzdělávání výchovy ke zdraví. V konceptu zdraví je uplatněno několik rovin zdraví, a to biologické, psychologické, sociální, ekologické a duchovní (stejné vymezení v pracích Pauluse, 2005). Pro účely vzdělávání je realizace holistického modelu (obr. 1) spatřována v pohledu na zdraví jako otevřeného konceptu životních podmínek jedince, jeho životního stylu a duševní pohody (srov. Jensen, 1997, s. 419-424).

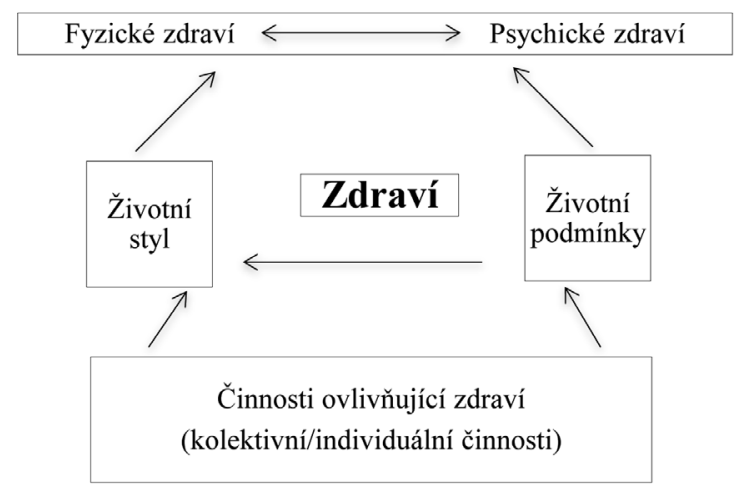

Obrázek 1. Holistický model zdraví; upraveno dle Jensena (1997, s. 424). Naznačené šipky v modelu poukazují na nutnost propojenosti jednotlivých dimenzí zdraví. Holistické pojetí zdraví funguje pouze za předpokladu vyrovnanosti všech složek zdraví prezentovaných v modelu.

4 Použijeme-li terminologii dle Jensena (1997), tedy přechod od moralistního paradigmatu zdraví (moralistic health paradigm) k demokratickému paradigmatu (democratic paradigm). Pojem moralistní je synonymním výrazem k pojmu biomedicinský a demokratický k pojmu holistický. 
Kirsten et al. (2009) vnímá holistický model zdraví z pohledu antropologického (obrázek 2). Model představuje holistické pojetí zdraví prostřednictvím pěti hlavních kontextových kategorií, které jsou rozděleny na kategorie základní a rozšiřující. Základní kategorie popisují zdraví jedince a poukazují na integrovanost těchto kategorií. Mezi základní kategorie patří kontext biologický, tedy bio-fyzické procesy (genetická výbava jedince, centrální nervový systém, endokrinní systém, dýchací a jiné systémy). Dále pak kontext psychologický (percepce, kognice, emoce, dispozice, sebereflexe atd.). Následující kategorii tvoří kontext spirituální (duchovní), který je charakterizován existenciálními procesy, interpretací konečné reality, morálními hodnotami týkajícími se vlastního pocitu zdraví atd. Model doplňují zbývající dvě kategorie: ekologický kontext zdraví (sociální, živé a neživé fyzické prostředí) a metafyzický kontext (symbolická a abstraktní složka každého jedince). Jednotlivé šipky naznačují reverzibilitu procesů týkajících se zdraví jedince.

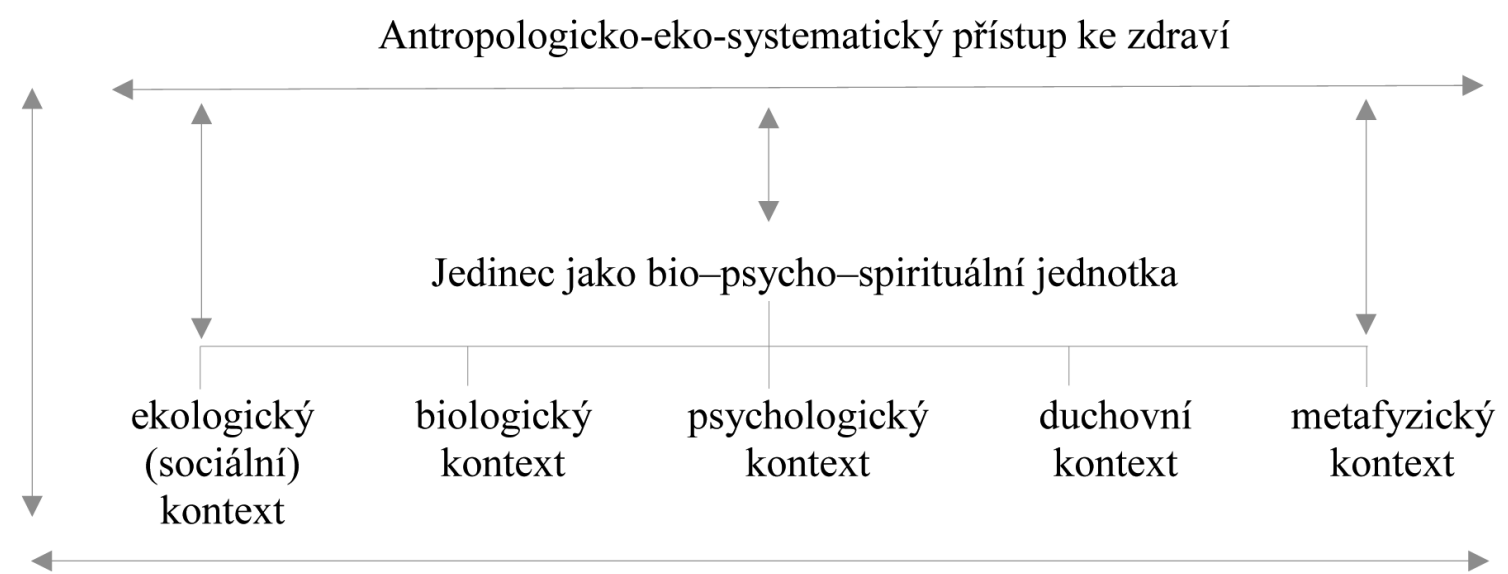

Obrázek 2. Model antropologického pojetí zdraví; upraveno dle Kirstena et al. (2009).

Holistický model zdraví umožňuje aplikaci výzkumné metody ve výzkumném šetření. Zdraví je vnímáno v co možná nejširším kontextu, který umožňuje nahlížet na vzdělávací oblast výchova ke zdraví v nových perspektivách. Tyto perspektivy plně podporují jedince, jeho osobnost, potřeby, dovednosti, vnímat a pozitivně využívat možnosti i limity jedince, a to dokonce i v předmětech, ve kterých bychom o integraci pro-zdravotního obsahu vzdělávání neuvažovali. Holistické pojetí zdraví se prolíná do uplatněné výzkumné 
metody, jednotlivé kontexty holistického modelu (Kirsten et al., 2009) a vnímání potřeby celistvosti při pohledu na prezentaci učiva týkajícího se zdraví (Jensen, 1997) vyústily v tvorbu základních kategorií kategoriálního systému užitého ve výzkumném šetření.

\section{Cíle a metody výzkumného šetření}

Cílem výzkumného šetření bylo analyzovat vzdělávací oblast výchova ke zdraví, prezentovanou $\mathrm{v}$ didaktickém aparátu učebnic prvouky a př́rodovědy 1 . stupně ZŠ. Tato analýza byla realizována z hlediska obsahové skladby učiva. Dalším cílem bylo zjistit, zda je v didaktickém aparátu učebnic primární školy zohledněno holistické pojetí zdraví.

\subsection{Výzkumný vzorek}

Vzhledem $\mathrm{k}$ cílům výzkumného šetření byly hlediskem pro volbu výběrového souboru takové učebnice, které byly součástí ucelené řady a současně v době transkribování a kódování dat (1. pololetí roku 2013) disponovaly platnou schvalovací doložkou MŠMT. ${ }^{5}$ Kritérium splňovalo pět učebnicových řad nakladatelství Fraus, Alter, Nová Škola, Didaktis a Prodos. Mluvíme tedy o učebnicích/cvičebnicích pro 1.-5. ročník základní školy (více $\mathrm{v}$ tabulce 1). Analytickou jednotkou obsahu (obsahové analýzy) je didaktický aparát učebnic. Celkem bylo transkribováno a analyzováno 3136 jednotek analýzy $(\mathrm{n}=3136)$.

\footnotetext{
5 Vybraných pět učebnicových řad prezentovalo maximálně možný výzkumný vzorek v rámci nastavených kritérií. Základním výzkumným souborem byly všechny řady učebnic prvouky a př́rodovědy pro primární školu s platnou schvalovací doložkou MŠMT. Předvýzkumný vzorek určený k ověření reliability výzkumného nástroje (kategoriálního systému) se sestával z pěti učebnic prvouky/přírodovědy (nakladatelství Fortuna/Alter), které měly platnou schvalovací doložku, ovšem nebyly součástí samotného výzkumného šetření.
} 
Tabulka 1

Rozvržení výzkumného vzorku

\begin{tabular}{|c|c|c|c|c|}
\hline Nakladatelství & & $\begin{array}{c}\text { Zastoupení vzdělávací } \\
\text { oblasti VKZ v učebnicích } \\
\text { primární školy } \\
\text { (1.-5. ročník) }\end{array}$ & $\begin{array}{c}\text { Typologie } \\
\text { didaktických textů }\end{array}$ & $\begin{array}{c}\text { Počet } \\
\text { jednotek } \\
\text { analýzy }\end{array}$ \\
\hline Fraus & 1.-5. ročník & Ano & $\begin{array}{c}5 \text { učebnic, } \\
4 \text { cvičebnice }\end{array}$ & 652 \\
\hline Alter & 1.-5. ročník & $\begin{array}{l}\text { Bez zastoupení VKZ } \\
\text { ve } 4 \text {. ročníku }\end{array}$ & $\begin{array}{c}5 \text { učebnic, } \\
4 \text { cvičebnice }\end{array}$ & 700 \\
\hline Didaktik & 1.-5. ročník & $\begin{array}{c}\text { Bez zastoupení VKZ } \\
\text { ve } 4 \text {. ročníku }\end{array}$ & $\begin{array}{c}4 \text { učebnice, } \\
3 \text { cvičebnice }\end{array}$ & 671 \\
\hline Prodos & 1.-5. ročník & $\begin{array}{l}\text { Učebnice a cvičebnice } \\
\text { pro 4. a 5. ročník je } \\
\text { prezentována v rámci } \\
\text { jedné učebnice } \\
\text { (1 cvičebnice). }\end{array}$ & $\begin{array}{l}4 \text { učebnice, } \\
2 \text { cvičebnice }\end{array}$ & 728 \\
\hline
\end{tabular}

\subsection{Výzkumné metody}

Pro účely našeho výzkumného šetření jsme zvolili za nosnou výzkumnou metodu obsahovou analýzu, která je definována jako procedura pro objektivní, systematický a kvantitativní popis zjevného obsahu komunikace (Berelson in Švec, 2009, s. 141). V rámci metodiky našeho výzkumu je obsahová analýza pojímána jako metoda na rozhraní metod kvalitativních a kvantitativních. Kvantifikace obsahových jednotek (otázek, úkolů a námětů k činnostem zařazených do didaktického aparátu učebnic prvouky a př́rodovědy pro primární školu) je realizována v rámci kvalitativních kategorií (biologická, psychologická, sociální, ekologická, duchovní dimenze pojetí zdraví).

Pro srovnání zjištěných výsledků analyzovaných učebnicových řad z nakladatelství Fraus, Alter, Nová škola, Didaktis a Prodos jsme použili metodu komparační analýzy (Keeves \& Adams, 1997, s. 31-41). Srovnávali jsme zastoupení makrokategorií a podkategorií celkově $\mathrm{v}$ učebnicových řadách i mezi jednotlivými ročníky zkoumaných učebnic. Při procesu kódování jednotek analýzy byl v kódovacím archu přidělen každé jednotce symbol 1 pro zařazení do př́slušné podkategorie kategoriálního systému. V ostatních př́padech (obsahové nepř́íslušnosti $\mathrm{k}$ dané podkategorii) byl jednotce obsahové analýzy přidělen symbol 0 . Následně byla provedena kvantifikace jednotek obsahové analýzy. V rámci obsahové a komparační analýzy byly uplatněny následující kvantifikační postupy: 
- zjištování četnosti (výskytu) analytických kategorií (makrokategorií, podkategorií);

- kvantifikace analytických kategorií se shodnou výpovědní hodnotou.

Kvantifikace jednotek obsahové analýzy nám umožnila zjistit jejich poměrné zastoupení a komparovat zjištěné četnosti $v$ rámci jednotlivých makrokategorií a podkategorií $\mathrm{v}$ rámci jednotlivých řad i ročníků analyzovaných učebnic. Při statistickém zpracování získaných dat jsme po zjištění absolutních a relativních četností jednotlivých kategorií a podkategorií přistoupili k jejich komparaci. Ke zjištění významných rozdílů v rámci jednotlivých kategorií a podkategorií ve zkoumaných učebnicových řadách jsme použili testu dobré shody chí-kvadrát s dodatkem o z-skóre testu (viz Chráska, 2010, s. 79-82). Kvantifikace jednotek obsahové analýzy nám umožnila zjistit jejich poměrné zastoupení a komparovat zjištěné četnosti v rámci jednotlivých kategorií a podkategorií.

\subsection{Tvorba kategoriálního systému}

Při vymezení jednotlivých kategorií vycházíme z holistického pojetí zdraví (Jensen, 1997; Kirsten et al., 2009; Paulus, 2005). Vycházeli jsme také z toho, že holistické pojetí zdraví v současnosti představuje nosnou koncepci v pohledu na zdraví a bylo začleněno do evropských dokumentů ${ }^{6}$ týkajících se zdravotní výchovy, jejichž akceptace spoluutváří zdravotní politiku ${ }^{7}$ u nás. Ve zmiňovaných dokumentech dochází k odklonu od biomedicínského pojetí $\mathrm{zdravi}^{8} \mathrm{k}$ pohledu komplexnímu, tedy holistickému.

6 Jedná se např. o ustanovení Světové zdravotnické organizace (WHO, 1986), kde prvotní zmínky o holistickém pojetí zdraví spadají do 50. let minulého století (podpora holistického modelu zdraví např. při zasedání World Council for Early Childhood Education, Paris, Archivní zdroje WHO, 1949, nepublikováno). Prezentaci holistického pojetí zdraví se věnují také dokumenty a ustanovení Evropské sítě škol podporujících zdraví (např. Clift \& Jensen, 2005), Zdraví pro všechny v 21. století (2002), vycházející z Health 21 (1998) atd.

7 Termínem zdravotní politika chápeme stanovisko nebo činnost určité instituce (zejména vlády) definující priority, dostupné zdroje a podmínky pro činnost, metody péče o zdraví, formy hodnocení výsledků a další politické okolnosti. Hlavním cílem zdravotní politiky je vytvořit a rozvíjet příznivé životní prostředí, v němž by lidé mohli žít zdravě (Holčík, 2010, s. 285).

8 V biomedicínském pojetí zdraví je zdraví považováno za stav bez prokázaných nemocí. Ve středu zkoumaného zájmu jsou diagnostická kritéria a symptomy nemocí (Holčík, 2010, s. 279). 
Jednotlivé kategorie jsme pro potřeby výzkumného šetření zúžili. Zároveň jsme je sjednotili s požadavky kladenými na vzdělávací oblast výchova ke zdraví pro primární vzdělávání prezentované v kurikulu státní úrovně (RVP ZV, 2013). U určování podkategorií je dbáno na to, aby byly kategorie disjunktní a plně vyčerpávající z hlediska klasifikace jednotek.

Kategoriální systém prošel několika vývojovými stádii. Prvotní návrh představoval šest základních kategorií (biologická, psychologická, sociální, ekologická, duchovní a kontextová kategorie). Výrazným nedostatkem původního systému bylo pouhé povrchní kategorizování výzkumných dat. Druhá verze kategoriálního systému se vyznačovala určitou přemírou podkategorií rozvíjejících kategorie základní. Předvýzkumné šetření poukázalo na nedostatky kategoriálního systému, které jsme se v rámci jeho finální verze snažili eliminovat.

Následující tabulka (tabulka 2) prezentuje finální verzi kategoriálního systému, který byl podroben předvýzkumným šetřením ${ }^{9} \mathrm{~s}$ cílem ověření jeho reliability. Zde došlo k zjištování př́ímé shody mezi kódovateli v procentech a koeficientu Cohenova kappa. ${ }^{10}$

9 Předvýzkumný vzorek tvoří pět učebnic prvouky pro primární školu nakladatelství Fortuna a Alter s platnou schvalovací doložkou MŠMT s celkovým počtem jednotek analýzy (n = 359). K ověření spolehlivosti výzkumného nástroje bylo užito kódování dvěma nezávislými kódovateli. Podrobný popis předvýzkumného šetření obsahuje disertační práce (Hrozová, 2014).

10 Koeficient Cohenovo kappa $(\kappa=0,94)$ měřil míru shody dvou kódovatelů, kteří hodnotili stejný počet výzkumných dat (jednotka zkoumání: didaktický aparát učebnic prvouky a př́rodovědy primární školy, $\mathrm{n}=359$ ). Reliabilita výzkumného nástroje byla potvrzena (přímá shoda $94 \%$ ). 
Tabulka 2

Finální verze kategoriálního systému

\begin{tabular}{|c|c|c|c|}
\hline Kategorie & Podkategorie & Označení & Obsahové vymezení podkategorie \\
\hline \multirow[t]{6}{*}{$\mathrm{BIO}$} & $\begin{array}{l}\text { Fyziologický } \\
\text { vývoj jedince }\end{array}$ & B1 & $\begin{array}{l}\text { Stavba lidského těla, základní funkce, projevy } \\
\text { a životní potřeby člověka, základy lidské } \\
\text { reprodukce, pohlavní rozdíly mezi mužem a ženou, } \\
\text { biologické změny v dospívání, vývojová stádia } \\
\text { jedince, smysly. }\end{array}$ \\
\hline & $\begin{array}{l}\text { Biorytmus } \\
\text { organismu, } \\
\text { hygienické } \\
\text { návyky }\end{array}$ & B2 & $\begin{array}{l}\text { Režim dne, pitný režim, hygienické návyky, } \\
\text { vyváženost psychické a fyzické zátěže. }\end{array}$ \\
\hline & $\begin{array}{l}\text { Sportovně } \\
\text { pohybová } \\
\text { aktivita }\end{array}$ & B3 & $\begin{array}{l}\text { Pohybový režim dne, působení pohybové aktivity } \\
\text { na organismus. }\end{array}$ \\
\hline & $\begin{array}{l}\text { První pomoc, } \\
\text { nemoci, } \\
\text { prevence }\end{array}$ & B4 & $\begin{array}{l}\text { Podání první pomoci, drobné úrazy a poranění, } \\
\text { nemoci přenosné a nepřenosné, př́iznaky nemocí, } \\
\text { prevence nemocí a úrazů (včetně prevence úrazů } \\
\text { způsobené dopravními nehodami, ochrana před } \\
\text { infekcemi přenosnými krví (hepatitida, HIV/AIDS). }\end{array}$ \\
\hline & $\begin{array}{l}\text { Dopravní } \\
\text { výchova }\end{array}$ & B4_A & $\begin{array}{l}\text { Předcházení rizikových situací v dopravě } \\
\text { a v dopravních prostředcích. }\end{array}$ \\
\hline & $\begin{array}{l}\text { Zdravý } \\
\text { životní styl, } \\
\text { péče o zdraví }\end{array}$ & B5 & $\begin{array}{l}\text { Zásady zdravého životního stylu a zdravé } \\
\text { (správné) výživy, výběr a způsoby uchovávání } \\
\text { potravin, vhodná skladba stravy, obezita, procesy } \\
\text { organismu při nesprávné životosprávě, biologické } \\
\text { projevy organismu na stres a jeho rizika. }\end{array}$ \\
\hline \multirow[t]{2}{*}{ PSYCHO } & $\begin{array}{l}\text { Rizikové } \\
\text { chování } \\
\text { a jednání } \\
\text { jedince } \\
\text { (návykové } \\
\text { látky } \\
\text { a zdraví) }\end{array}$ & P1 & $\begin{array}{l}\text { Chování poškozující zdraví (drogy, přenosné } \\
\text { nemoci), chování jedince a reflexe jeho chování } \\
\text { v rizikových situacích, agrese, zátěž a stres } \\
\text { ve škole, šikana, týrání, sexuální a jiné zneužívání, } \\
\text { návykové látky, hrací automaty a počítače, TV, } \\
\text { závislost, odmítání návykových látek, nebezpećí } \\
\text { komunikace prostřednictvím médií, brutalita } \\
\text { a jiné formy násilí v médiích. }\end{array}$ \\
\hline & $\begin{array}{l}\text { Zdravý } \\
\text { životní styl }\end{array}$ & P2 & $\begin{array}{l}\text { Způsob života, životospráva, duševní zdraví } \\
\text { a psychohygiena, vyváženost psychické a fyzické } \\
\text { zátěže, psychické změny v dospívání, psychické } \\
\text { reakce organismu na stres a jeho rizika, } \\
\text { psychosomatická onemocnění, nemoci. }\end{array}$ \\
\hline
\end{tabular}


Tabulka 2

(pokračování)

\begin{tabular}{|c|c|c|c|}
\hline Kategorie & Podkategorie & Označení & Obsahové vymezení podkategorie \\
\hline \multirow[t]{3}{*}{ SOC } & $\begin{array}{l}\text { Osobnostní } \\
\text { a sociální } \\
\text { rozvoj, rodina }\end{array}$ & $\mathrm{S} 1$ & $\begin{array}{l}\text { Dovednosti empatie, autenticity, kooperace, } \\
\text { analýza sociálních situací, sebepoznání, } \\
\text { sebereflexe, simulace a rozvoj sociálních } \\
\text { (interpersonálních) vztahů, rodina a partnerství, } \\
\text { respekt, rodina, vztahy v rodině, partnerské } \\
\text { vztahy, osobní vztahy. }\end{array}$ \\
\hline & $\begin{array}{l}\text { Sociální } \\
\text { kompetence } \\
\text { v návaznosti } \\
\text { na sociální } \\
\text { dovednosti }\end{array}$ & $\mathrm{S} 2$ & $\begin{array}{l}\text { Kultivace a podpora seberealizace, uplatnění } \\
\text { potenciálu jedince, vlastní důstojnost, jedinečné } \\
\text { hodnoty osobnosti, řešení problémů, uplatnění } \\
\text { vzorů a ideálů. }\end{array}$ \\
\hline & $\begin{array}{l}\text { Osobní } \\
\text { bezpečí, } \\
\text { krizové } \\
\text { situace }\end{array}$ & S3 & $\begin{array}{l}\text { Vhodná a nevhodná místa pro hru, bezpečné } \\
\text { chování v rizikovém prostředí, rozpoznání } \\
\text { a analýza nebezpečných situací, označování } \\
\text { nebezpečných látek, efektivní komunikace - } \\
\text { čísla tísňového volání, správný způsob volání } \\
\text { na tísňovou linku, přivolání pomoci v případě } \\
\text { ohrožení fyzického a duševního zdraví - služby } \\
\text { odborné pomoci, postup v případě ohrožení, } \\
\text { požáry, integrovaný záchranný systém. }\end{array}$ \\
\hline \multirow[t]{3}{*}{ EKO } & $\begin{array}{l}\text { Životní } \\
\text { prostředí }\end{array}$ & E1 & $\begin{array}{l}\text { Základní podmínky života, péče a aktuální stav } \\
\text { životního prostředí, obnovitelné zdroje, ochrana } \\
\text { přírody. }\end{array}$ \\
\hline & $\begin{array}{l}\text { Prostředí, } \\
\text { ve kterém } \\
\text { žijeme }\end{array}$ & E2 & $\begin{array}{l}\text { Pracovní prostředí a podmínky pro práci, zdravé } \\
\text { bydlení, stolování, vliv prostředí na zdraví, jejich } \\
\text { komplexní a synergické působení, možnosti } \\
\text { a způsoby ochrany zdraví skrze životní prostředí. }\end{array}$ \\
\hline & Životní styl & E3 & $\begin{array}{l}\text { Spotřeba věcí, energie, odpady, způsoby jednání } \\
\text { člověka a vliv vlastního životního stylu jedince } \\
\text { na prostředí, voda, čistota. }\end{array}$ \\
\hline \multirow[t]{3}{*}{ DUCH } & $\begin{array}{l}\text { Lidské } \\
\text { hodnoty }\end{array}$ & D1 & $\begin{array}{l}\text { Humanistický obraz člověka, zdraví jako prvořadá } \\
\text { hodnota, poznání sebe sama jako živé bytosti, } \\
\text { pochopení hodnoty zdraví, smysl rodiny, etická } \\
\text { stránka vztahů, etická stránka sexuality. }\end{array}$ \\
\hline & $\begin{array}{l}\text { Tradice } \\
\text { vedoucí } \\
\text { k porozumění }\end{array}$ & D2 & $\begin{array}{l}\text { Pomoc druhým, péče o staré lidi, o malé děti, } \\
\text { o osoby s handicapem, funkce domova, hodnota } \\
\text { člověka, altruistické chování. }\end{array}$ \\
\hline & Smysl života & D3 & $\begin{array}{l}\text { Vlastní životní cesta, duchovní a existencionální } \\
\text { rozměr člověka, reflexe změn v životě jedince, } \\
\text { smysl zdravotní prevence, hloubka problémů } \\
\text { spojených s nemocí či jiným poškozením zdraví. }\end{array}$ \\
\hline
\end{tabular}


Tabulka 2

(pokračování)

\begin{tabular}{llcl}
\hline Kategorie & Podkategorie & Označení & Obsahové vymezení podkategorie \\
\hline $\begin{array}{l}\text { MEZI- } \\
\text { OBOROVÉ } \\
\text { PROPOJENÍ1 }\end{array}$ & Matematika & M1 & Kategorie přesahující do matematiky. \\
\cline { 2 - 4 } & $\begin{array}{l}\text { Výtvarná } \\
\text { výchova }\end{array}$ & M2 & Kategorie přesahující do výtvarné výchovy. \\
\hline OSTATNí1 ${ }^{12}$ & KX & $\begin{array}{l}\text { Kategorie nikterak obsahově nenavazující } \\
\text { na výchovu ke zdraví a ostatní nezařaditelný } \\
\text { didaktický aparát učebnic. }\end{array}$ \\
\hline
\end{tabular}

\section{Výsledky výzkumného šetření}

V kapitole představujeme vybrané výsledky výzkumného šetření. Přesněji tedy výsledky analýzy vzdělávací oblasti výchova ke zdraví, prezentované v didaktickém aparátu učebnic pro primární školu (učebnice/cvičebnice prvouky/přírodovědy). Nejprve se věnujeme analýze kategorií celého výzkumného souboru, poté se soustředíme na komparaci jednotlivých ročníků všech zkoumaných učebnicových řad nakladatelství Fraus, Alter, Nová škola, Didaktis a Prodos, kde statisticky významné rozdíly výskytu mezi jednotlivými kategoriemi $v$ jednotlivých ročnících zkoumaných učebnicových řad dokladují výsledky chí-kvadrát testu s dodatkem o z-skóre testu. ${ }^{13}$

\subsection{Profilace kategorií v souhrnném šetření}

Komparační šetření provedené mezi ročníky analyzovaných učebnic prvouky a př́rodovědy pro základní školu přineslo informace o obsahovém vymezení vzdělávací oblasti výchova ke zdraví prezentované v učebnicích. Učebnicové

11 Předvýzkumným šetřením bylo zjištěno statisticky významné propojení výchovy ke zdraví $\mathrm{v}$ učebnicích prvouky/př́rodovědy pro 1 . stupeň ZŠ pouze se vzdělávacím oborem Matematika a její aplikace a Výtvarná výchova.

12 Kategorie Ostatní KX primárně shromažd'uje takový didaktický aparát učebnic, který přestože je součástí výchovy ke zdraví v učebnicích, obsahově nikterak nereprezentuje vzdělávání v oblasti zdraví. Sekundárně pak sdružuje didaktický aparát učebnic, který nebylo možno kategorizovat dle předloženého kategoriálního systému.

13 Vypočítané hodnoty testového kritéria z (z-skóre) se simultánně testovaly na třech hladinách významnosti $p$, přičemž pokud je pozorovaná četnost výrazně větší/menší než četnost očekávaná na hladině významnosti $\mathrm{p}<0,001$, kritérium $\mathrm{z}$ (z-skóre testu) se pohybuje $\mathrm{v}$ hodnotách 3,3 $\mathrm{z}$, pro hladinu významnosti $\mathrm{p}<0,01 ; 2,58<\mathrm{z} \mathrm{z}<3,3$ a pro hladinu významnosti $\mathrm{p}<0,05 ; 1,96$ z < 2,58 (viz Chráska, 2010, s. 80-81). 
řady nakladatelství Fraus, Alter, Didaktis, Nová škola a Prodos mají vysoké zastoupení didaktického aparátu v kategorii B Biologické 67 \%, přičemž zastoupení této kategorie je vyšší u učebnic nakladatelství Didaktis 69 \% a nižší u učebnic nakladatelství Fraus 57 \%. Tato skutečnost poukazuje na celkové zaměření učebnic na biologický kontext zdraví. Takové zaměření plně nepodporuje holistické pojetí zdraví a naznačuje, že v učebnicích dominuje biomedicínské pojetí zdraví. Kategorie S Sociální je zastoupena $11 \%$ a je jedinou kategorií systému, která společně s kategorií $B$ Biologické ve všech učebnicích vykazuje hodnotu relativní četnosti vyšší než 10 \%. Kategorie S Sociální je specifická rovnoměrným rozložením didaktického aparátu v učebnicových řadách, vyjma učebnic nakladatelství Nová škola, kde je zastoupení méně než $6 \%$. Ostatní kategorie se, v celkovém hodnocení, pohybují v hodnotách relativní četnosti mezi 3-6\%. Zajímavé je zjištění týkající se kategorie E Ekologické, v rámci které je charakteristické významně vyšší zastoupení v učebnicích nakladatelství Fraus $14 \%$, přičemž ostatní sledované učebnicové řady vykazují výrazně nižší zastoupení $3-5 \%$. Tab. 3 prezentuje hodnoty absolutní četnosti naměřené pro jednotlivé základní kategorie systému platné pro zkoumané učebnicové řady a odpovídající hodnoty chí-kvadrát testu pro jednotlivé kategorie. ${ }^{14}$

Tabulka 3

Rozdíl výskytu kategorií v učebnicových řadách nakladatelství Fraus, Alter, Nová škola, Didaktis a Prodos

\begin{tabular}{llllllll}
\hline & B & P & S & E & D & M & KV \\
\hline Alter & $\mathbf{5 1 3}$ & 10 & 71 & 21 & 25 & 20 & 40 \\
\hline Didaktis & 466 & 16 & 79 & 23 & $\mathbf{3 1}$ & 15 & 41 \\
\hline Fraus & 369 & 21 & 87 & $\mathbf{9 1}$ & 27 & 18 & 39 \\
\hline $\begin{array}{l}\text { Nová } \\
\text { škola }\end{array}$ & 287 & 10 & 23 & 18 & 7 & 14 & 26 \\
\hline Prodos & 473 & $\mathbf{3 7}$ & $\mathbf{9 4}$ & 21 & 24 & $\mathbf{3 5}$ & $\mathbf{4 4}$ \\
\hline$\sum$ & 2108 & 94 & 354 & 174 & 114 & 102 & 190 \\
\hline$\chi^{2}$ & $64,09^{* * *}$ & $17,71^{* *}$ & $15,30^{* *}$ & $108,56^{* * *}$ & 6,06 & $8,68^{*}$ & 0,48 \\
\hline
\end{tabular}

Pozn. ${ }^{*} \mathrm{p}<0,05$; ** $\mathrm{p}<0,01$; ** $\mathrm{p}<0,001$; Nejvyšší dosažené hodnoty absolutní četnosti v jednotlivých kategoriích jsou vyznačeny tučně. Popis kategorií: B Biologická, P Psychologická, S Sociální, E Ekologická, D Duchovní, M Mezioborové propojení a KX Ostatní.

14 Ke zjištění významných rozdílů v rámci jednotlivých kategorií a podkategorií ve zkoumaných učebnicových řadách jsme použili testu dobré shody chí-kvadrát testu a testové kritérium $\mathrm{z}$ (z-skóre), přičemž operujeme na třech hladinách významnosti $\mathrm{p}$, kde symbol ${ }^{* * *}$ zastupuje hladinu významnosti $\mathrm{p}<0,001$; symbol** reprezentuje hladinu významnosti $\mathrm{p}<0,01$ a symbol * označuje hladinu významnosti $\mathrm{p}<0,05$. 
Rozlišné hodnoty chí-kvadrát testu uvedené v tabulce poukazují na nekonzistentnost $\mathrm{v}$ rozvržení didaktického aparátu a podávají zprávu o obsahovém vymezení výchovy ke zdraví v učebnicích jednotlivých vydavatelství. Kategorie, jejichž hodnoty jsou distribuovány v rámci celého zkoumaného vzorku rovnoměrně (jedná se o kategorii $D$ Duchovní), však bohužel vykazují nízkou hodnotu absolutní i relativní četnosti.

S odvoláním na výsledky výzkumného šetření můžeme konstatovat, že tradiční či klasickou profilaci obsahu vzdělávání v oblasti zdraví v učebnicích prvouky a přírodovědy, můžeme nazvat jako bio-sociální. Ta je uplatňována v učebnicových řadách nakladatelství Alter, Didaktis a Prodos. Učebnicovou řadu nakladatelství Fraus můžeme klasifikovat jako bio-eko-sociální, zohledňující možnosti prezentace výchovy ke zdraví v učebnicích primární školy i v jiném pojetí nežli bio-sociálním. Poslední učebnicová řada nakladatelství Nová škola je dominantně biologická. Ostatní kategorie systému prezentující holistické pojetí zdraví (kategorie psychologická a duchovní) nejsou preferovány tvůrci žádné zkoumané učebnicové řady.

Pro potřeby tohoto příspěvku se v následujících odstavcích detailněji zaměřujeme na dvě nejčetněji zastoupené kategorie, a to kategorii Biologickou a Sociální. Ukazuje se, že komparace zkoumaných jednotek v jednotlivých ročnících v kategorii Biologické $(\mathrm{n}=2108)$ upozornila na výraznou obsahovou variabilitu mezi jednotlivými učebnicovými řadami. Došlo ke zjištění statisticky významně nižších hodnot prezentujících zastoupení didaktického aparátu v 1. ročníku u učebnice Prodos $(\mathrm{z}=-2,73) ; \mathrm{v} 2$. ročníku významně nižších hodnot u učebnic Fraus $(\mathrm{z}=-2,24)$ a vyššího zastoupení u učebnice Nová škola $(z=3,98)$; ve 3 . ročníku výrazně nižších hodnot u učebnic Fraus $(\mathrm{z}=-2,96)$ a výrazně nižších u učebnice Fraus $(\mathrm{z}=-2,80)$ v 5 . ročníku.

Za zcela nevyváženou a silně narušující celkovou koncepci výchovy ke zdraví na 1. stupni ZŠ považujeme absenci tematiky zdraví ve 4. ročnících u učebnic nakladatelství Alter, Didaktis a Nová škola (obr. 3, 4). Nakladatelství Prodos pro výchovu ke zdraví koncipovalo samostatnou učebnici/cvičebnici Výchovy ke zdraví pro 4. a 5. ročník. Nevíme však, jak si s výzvou týkající se rozvržení obsahu vzdělávání oblasti zdraví do dvou ročníků poradí praxe. Pouze učebnicová řada nakladatelství Fraus nepodlehla trendu vynechání vzdělávání v oblasti zdraví ve 4. ročníku ZŠ. Nárůst zkoumaných jednotek byl zaznamenán u všech učebnic 5. ročníků, což si vysvětlujeme absencí vzdělávání ve 4. ročníku, a tudíž určitou nutností před ukončením vzdělávání na 1. stupni ZŠ „,dohnat“ vše, co bylo obsahově vymezeno RVP ZV (více obr. 3). 


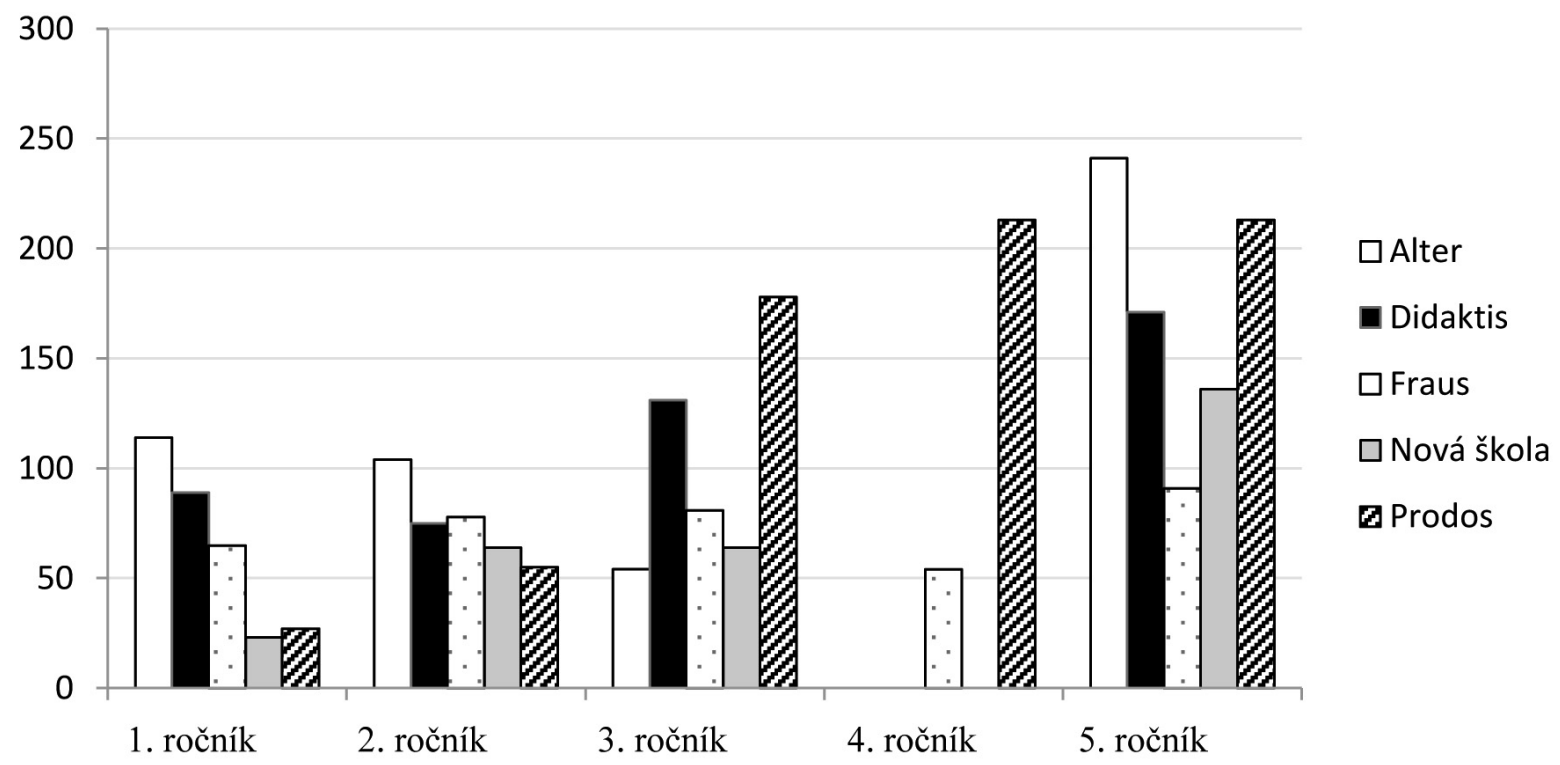

Obrázek 3. Poměr výskytu kategorie B Biologické v komparaci jednotlivých ročníků učebnicových řad nakladatelství Alter, Didaktis, Fraus, Nová škola a Prodos (v absolutních četnostech, $\mathrm{n}=2108){ }^{15}$

Co se poměru výskytu kategorie Sociální $(\mathrm{n}=354)$ týče, je situace v porovnání s kategorií Biologickou odlišná. Komparace prvních ročníků přinesla informace o výrazně nižším zastoupení zkoumaných jednotek u nakladatelství Alter $(\mathrm{z}=-3,03)$, dále bylo zjištěno výrazně nižší zastoupení ve 2 . ročníku učebnice Nová škola $(\mathrm{z}=-2,84)$, významně nižší zastoupení zkoumaných jednotek v učebnici Didaktis $(\mathrm{z}=-3,13)$ v 5. ročníku (více obr. 4).

Detailní analýza učebnic za jednotlivé ročníky a učebnicové řady včetně charakteristiky všech kategorií a podkategorií je součástí disertační práce (Hrozová, 2014).

15 Statisticky významné rozdíly hodnot chí-kvadrát testu pro kategorii Biologickou pro 1. ročník $(\chi 2=19,01 ; p<0,001) ; 2$. ročník $(\chi 2=23,15 ; p<0,001) ; 3$. ročník $(\chi 2=12,97$; $\mathrm{p}<0,05)$ a 5 ročník $(\chi 2=20,80 ; \mathrm{p}<0,001)$. 


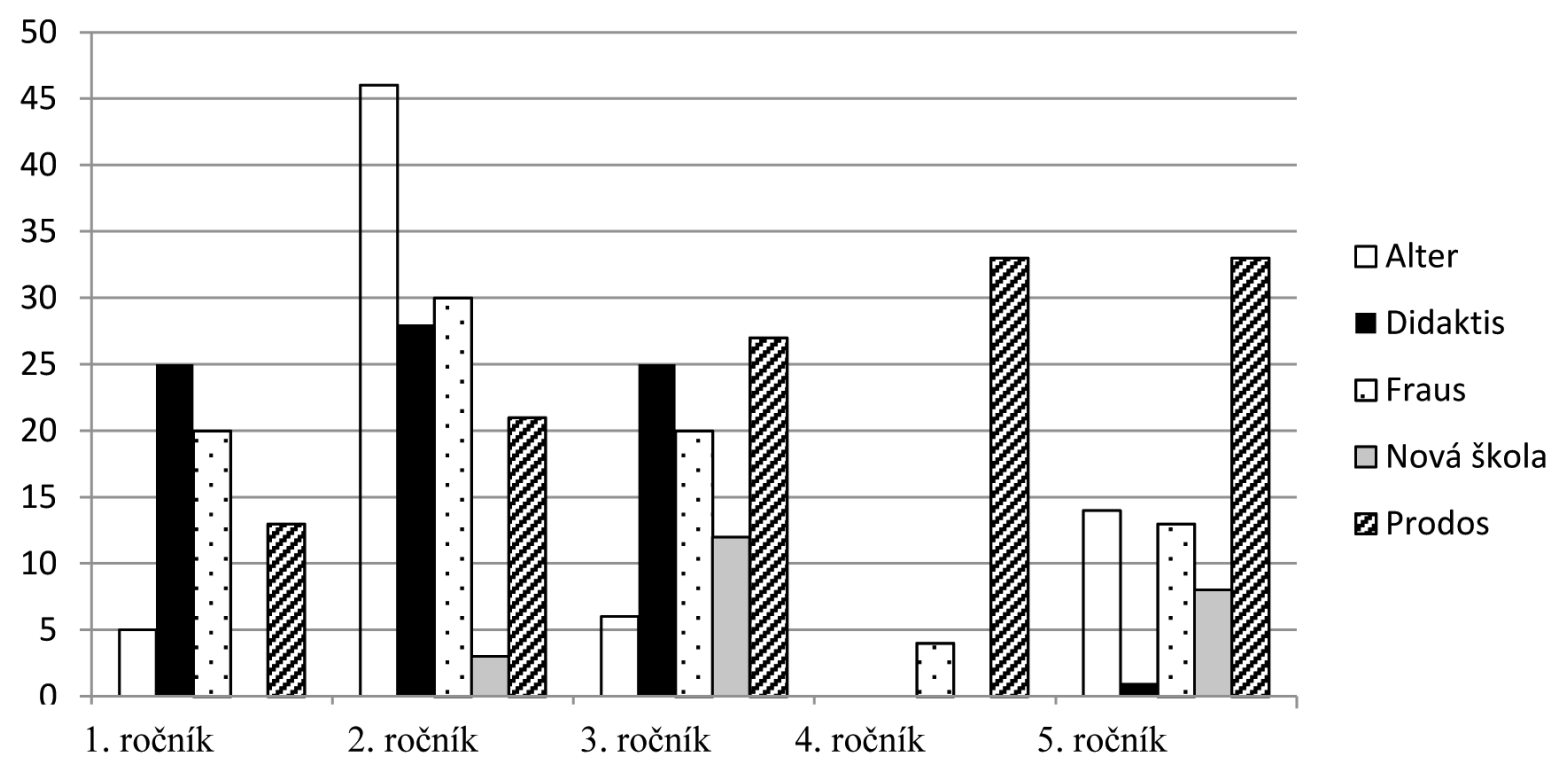

Obrázek 4. Poměr výskytu kategorie $S$ Sociální v komparaci jednotlivých ročníků učebnicových řad nakladatelství Alter, Didaktis, Fraus, Nová škola a Prodos (v absolutních četnostech, $\mathrm{n}=354$ ). ${ }^{16}$

\section{Diskuse}

Jsme si vědomi určitých limitů determinujících výsledky našeho šetření, které vycházejí z několika níže prezentovaných aspektů. Problémem, s nímž jsme se při koncipování našeho výzkumu potýkali, je fakt, že výzkumy monitorující obsah vzdělávání v oblasti výchova ke zdraví prezentované v učebnicích v českém prostředí absentují. Nebylo tedy možné inspirovat se jiným obdobně koncipovaným výzkumem, který by kategorizoval obsah vzdělávání v oblasti zdraví. Pro kategorizaci výzkumných dat jsme si vybrali holistický model zdraví, který jsme obsahově zúžili a následně sjednotili s vymezením výchovy ke zdraví, tak jak je prezentovaná v RVP ZV (2013).

Výsledky výzkumného šetření naznačily, že obsahové strukturaci didaktického aparátu ve zkoumaných učebnicích chybí logická návaznost, propojenost, cyklické opakování a postupné nabývaní obsahu vzdělávání (více v kap. 4). Konkrétní tematické celky jsou distribuovány různě a v odlišném množství v jednotlivých učebnicových řadách. Žáci se tedy seznamují s odlišným

16 Statisticky významné rozdíly hodnot chí-kvadrát testu pro kategorii Sociální pro 1. ročník $\left(\chi^{2}=19,82 ; p<0,001\right) ; 2$. ročník $\left(\chi^{2}=12,80 ; p<0,05\right)$ a 5. ročník $\left(\chi^{2}=22,60 ; p<0,001\right)$. 
pojetím výchovy ke zdraví v závislosti na konkrétní učebnicové řadě. To dokládá nerovnoměrné zastoupení didaktického aparátu $v$ jednotlivých kategoriích a podkategoriích podporujících holistické pojetí zdraví.

Důvodem vzájemné odlišnosti učebnic může být, že kurikulární dokument (RVP ZV, 2007, 2013) z něhož apriorně obsahově vycházejí, nepředstavuje dostatečnou podporu v oblasti obsahového, potažmo cílového vymezení výchovy ke zdraví na 1 . stupni ZŠ. Tato skutečnost by se mohla eliminovat posílením normativní funkce učebnic, která by „vedle osnov a standardů také svým pojetím a zpracováním vymezovala rozsah poznatků, předkládaných k osvojení žáky“ (Maňák, Janík, \& Švec, 2008, s. 41) s důrazem na vymezení jednotného, přiměřeného základního učiva (srov. Knecht, 2007). Jelikož se výzkumné šetření prezentované ve studii nedotýká realizovaného kurikula, zůstává otázkou, jak s obsahem vzdělávání v oblasti výchova ke zdraví nakládá samotný učitel. Vzhledem k multidisciplinární povaze výchovy ke zdraví, která integruje poznatky z různých oborů, by se procesům didaktické transformace stejně jako didaktice výchovy ke zdraví měla věnovat zvýšená pozornost. Učebnice a její prezentace obsahu vzdělávání podává cenné informace o výběru obsahu v konkrétní oblasti vzdělávání, ve smyslu konečného výsledku didaktických transformací. $K$ tématu obecné specifičnosti učebnic prvouky je nutno podotknout, že „pojetí prvouky není jasně zakotveno v žádném vědním oboru a je do značné míry určováno profesionálnímu zaměření tvůrců osnov a učebnic“ (Dvořák, Dvořáková, \& Stará, 2008, s. 85) a odborné texty $\mathrm{k}$ didaktice prvouky se zabývají pouze biologií a přírodovědou (Podroužek, 2004), což znesnadňuje začlenění relativně nových obsahů do učebnic tohoto typu.

Komparační šetření týkající se jednotlivých ročníků všech analyzovaných učebnicových řad poukázalo na skutečnost, že učebnice určené pro žáky 2. ročníků všech nakladatelství můžeme označit jako bio-sociální se snahou o eko-duchovní kontext. Ostatní ročníky učebnic jsou zaměřeny na kontext zdraví bio-sociální, přičemž biologické zaměření vzdělávání v oblasti zdraví převládá ve 4. a 5. ročnících. Podpoře holistického zdraví se nejvíce přibližuje pojetí výchovy ke zdraví prezentované v učebnicové řadě nakladatelství Fraus. Ryze biologický kontext zdraví prezentovaný v učebnicích primární školy můžeme pozorovat již $\mathrm{v}$ učebnicích prvouky ze 70. let minulého století (např́íklad v učebnicích prvouky Tupý \& Szathmáryová-Vlčková, 1973a, 1973b, 1977, 1982), kde je zajímavé sledovat nejen didaktický aparát učebnic, ale i jejich mimotextové prvky učebnic, které vykazují výrazné znaky podobnosti se současnými učebnicemi. 


\section{Závěr}

Studie se zaměřuje na analýzu vzdělávání v oblasti výchova ke zdraví v didaktickém aparátu učebnic prvouky/prrírodovědy platných pro 1. stupeň ZŠ. Zajímá nás, jaké pojetí zdraví je uplatněné v rámci obsahové skladby didaktického aparátu učebnic 1 . stupně ZŠ. Výchova ke zdraví se v oblasti primárního vzdělávání etablovala díky zavedení Standardu základního vzdělávání (1995). Do kurikula státní úrovně pronikla se zavedením RVP ZV (2007). Obsahové vymezení výchovy ke zdraví se díky zmiňovaným kurikulárním dokumentům jen mírně modifikovalo, čemuž se přizpůsobilo i pojetí tematiky zdraví v učebnicích 1. stupně ZŠ. Ačkoliv analyzované učebnice deklarují návaznost prezentovaných obsahů týkajících se tematiky zdraví na kurikulární dokumenty (Marádová, 2008), ve výsledcích našeho výzkumného šetření byly zjištěny značné rozdíly $\mathrm{v}$ obsahovém vymezení tematiky zdraví u jednotlivých učebnicových řad.

V rámci celého výzkumného vzorku $(\mathrm{n}=3136)$ bylo zjištěno dominantní zastoupení kategorie $B$ Biologické $67 \%$, které poukazuje na obsahové zaměření učebnic 1. stupně ZŠ na biologický kontext zdraví. Zjištění majoritního postavení kategorie $B$ Biologické v rámci didaktického aparátu učebnic bylo naším předpokladem. Pojetí obsahu výchovy ke zdraví zaměřené na biologický kontext zdraví poukazuje na to, že holistický model zdraví není v učebnicích prvouky/přírodovědy ve větší míře reflektován.

Co se týče zastoupení ostatních kategorií, pouze kategorie $S$ Sociální dosahuje vyšší hodnoty relativní četnosti 11 \%. Ostatní kategorie dosahují hodnot relativních četností 3-6 \%. Významným zjištěným deficitem didaktického aparátu učebnic $\mathrm{v}$ oblasti výchova ke zdraví je prezentace učiva této oblasti $\mathrm{v}$ učebnicích pro 4. ročník. $\mathrm{V}$ didaktickém aparátu většiny zkoumaných učebnicových řad zcela absentuje zastoupení tematiky výchovy ke zdraví v učebnicích pro 4. ročník. Výjimkou jsou pouze učebnice z nakladatelství Fraus a Prodos. V učebnici Prodos se ovšem výchova ke zdraví realizuje v rámci dvou-ročníkové učebnice společné pro 4. a 5. ročník, kde není specificky ujasněno, který obsah vzdělávání je určen pro 4. a který pro 5. ročník.

Navržený kategoriální systém může sloužit rovněž tvưrcům učebnic a metodických příruček týkajících se vzdělávací oblasti člověk a jeho svět jako inspirativní obsahový či evaluační materiál. Samotným učitelům pak může posloužit k reflexi obsahového zastoupení vzdělávací oblasti člověk a jeho svět v pedagogické praxi a také jako opora při výběru učebnic. 
Mezi možnosti navazujícího výzkumného šetření považujeme vstup výzkumníka do terénu se zaměřením na učitele (na jeho subjektivní teorie, postoje a př́stupy $\mathrm{k}$ tematice zdraví, na učitele jako realizátora kurikula) a na žáky (jako př́ijemce kurikula). Další navazující multidisciplinární výzkumnou cestou by mohl být výzkum zaměřený na sémantický charakter předloženého kategoriálního systému. Možnou nabízející se variantou je také výzkum historicko-srovnávací, zabývající se vývojem učebnic prvouky. Jak jsme se již zmiňovali výše, mnohé obsahové prvky z oblasti výchovy ke zdraví prezentované $\mathrm{v}$ učebnicích jsou uplatňovány již od 70 . let minulého století. Bylo by zajímavé podat detailnější informace, které by nám umožnily pochopit zažité stereotypy ve vzdělávání $v$ oblasti zdraví a snad je i pomohly překonat.

\section{Literatura}

Brockmeyerová-Fenclová, J., Čapek, V., \& Kotásek, J. (2000). Oborové didaktiky jako samostatné vědní disciplíny. Pedagogika, 50(1), 23-37.

Dvořák, D., Dvořáková, M., \& Stará, J. (2008). Design based research - výzkum učebnic prováděný jejími tvůrci. In P. Knecht \& T. Janík, et al., Učebnice z pohledu pedagogického výzkumu (s. 81-89). Brno: Paido.

Holčík, J. (2010). Systém péče o zdraví a zdravotní gramotnost. Brno: MSD.

Hrozová, M. (2014). Analýza vzdělávací oblasti výchova ke zdraví v didaktickém aparátu učebnic primární školy (Disertační práce). Dostupné z http://is.muni.cz/th/104606/pedf_d/DsP_ Hrozova.pdf

Chráska, M. (2010). Metody pedagogického výzkumu: základy kvantitativního výzkumu. Praha: Grada.

Janík T., \& Slavík, J. (2007). Vztah obor - vyučovací předmět jako metodologický problém. Orbis Scholae, 2(1), 54-66.

Jensen, B. B. (1997). A case of two paradigms within health education. Health Educational Research, 12(4), 418-428.

Kebza, V. (2005). Psychosociální determinanty zdraví. Praha: Academia.

Keeves, J. P., \& Adams, D. (1997). Comparative methodology in education. In J. P. Keeves (Ed.), Educational research, methodology and measurement: An international handbook (s. 31-41). London: Pergamon.

Kirsten, T. G. J. C., Van der Walt, H. J. L., \& Viljoen, C. T. (2009). Health, wellbeing and wellness: An anthropological eco-systemic approach. Health SA Gesondheid, 14(1). Dostupné z http:// www.hsag.co.za/index.php

Knecht, P. (2007). Didaktická transformace aneb od didaktického zjednodušení k didaktické rekonstrukci. Orbis scholae, 2(1), 67-81.

Liba, J. (2008). Výchova k zdraviu ako súčast’ výchovného komplexu v školách. Pedagogická orientace, 18(3), 53-62.

Maňák, J., Janík, T., \& Švec, V. (2008). Kurikulum v současné škole. Brno: Paido.

Marádová, E. (2008). Výchova ke zdraví na cestě od Rámcového vzdělávacího programu k realizaci ve školní praxi. In E. Řehulka, et al. (Eds.), School and health 21, Současný diskurz zkoumání školy a zdraví (s. 23-28). Brno: MSD. 
Mužíková, L. (2010). Podněty pro implementaci výchovy ke zdraví do školních vzdělávacích programů. Brno: Masarykova univerzita.

Paulus, P. (2005). From the health promoting school to the good and healthy school: New developments in Germany. In S. Clift \& B. B. Jensen (Eds.), The health promoting school: International advances in theory, evaluation and practice (s. 55-75). Copenhagen: DPU.

Podroužek, L. (2004). Úvod do didaktiky prvouky a př́rodovědy pro primární školu. Dobrá Voda: POLS.

Průcha, J. (1998). Učebnice: teorie a analýzy edukačnîho média. Brno: Paido.

Rámcový vzdělávací program pro základní vzdělávání. (2007). Dostupné z http://www.nuv.cz/ file/137/

Rámcový vzdělávací program pro základní vzdělávání. (2013). Dostupné z http://www.nuv.cz/ folder/18/

Skalková, J. (2007). Obecná didaktika. Praha: Grada Publishing.

Standard základního vzdělávání. (1995). Dostupné z http://aplikace.msmt.cz/HTM/Standard_ ZV.htm

Švec, Š., et al. (2009). Metodologie věd o výchově. Kvantitativně-scientické a kvalitativněhumanitní př́stupy v edukačním procesu. Brno: Paido.

Tupý, K., Nečesaná, J., \& Szathmáryová-Vlčková, V. (1977). Prvouka v 2. ročníku ZDŠ: pracovné listy pre žiakov. Bratislava: SPN.

Tupý, K., \& Szathmáryová-Vlčková, V. (1973a). Prvouka v 1. ročníku ZDŠ: pracovné listy pre žiakov. Bratislava: SPN.

Tupý, K., \& Szathmáryová-Vlčková, V. (1973b). Prvouka v 2. ročníku ZDŠ: pracovné listy pre žiakov: experimentálna učebnica VÚP. Bratislava: SPN.

Tupý, K., \& Szathmáryová-Vlčková, V. (1982). Prvouka v 1. ročníku základnej školy: pracovné listy pre žiakov. Bratislava: SPN.

Usnesení vlády a popis cílů programu Zdraví pro všechny v 21. století. Dlouhodobý program zlepšování zdravotního stavu obyvatelstva ČR. (2001). Dostupné z http://www.mzcr.cz/ Verejne/dokumenty/zdravi-pro-vsechny-v-stoleti_2461_1101_5.html

World Health Organization (1947). Constitution of the World Health Organization. Chronicle of the World Health Organization, Annex 1. Copenhagen: Technical Secretariat, WHO. Dostupné z http://whqlibdoc.who.int/hist/chronicles/chronicle_1947.pdf

World Health Organization (1985). Targets for health for all by the year 2000. Copenhagen: WHO.

World Health Organization (1986). The Ottawa Charter for health promotion. Health Promotion, 1 , iii-v.

World Health Organization (1998). Health21: An introduction to the health for all policy framework for the WHO European region. Dostupné z http://www.euro.who.int/_data/ assets /pdf_file/0010/98398/wa540ga199heeng.pdf

\section{Analyzované učebnice:}

Adámková, P., et al. (2007). Člověk a jeho svět: pro 2. ročník základní školy: pracovní sešit. Brno: Didaktis.

Adámková, P., et al. (2007). Člověk a jeho svět: učebnice pro 2. ročník základní školy. Brno: Didaktis.

Danihelková, H., \& Malý, R. (2007). Člověk a jeho svět. Pracovní sešit pro 3. ročník ZŠ. Olomouc: Prodos. 
Danihelková, H., \& Malý, R. (2007). Člověk a jeho svět. Učebnice pro 2. ročník ZŠ. Olomouc: Prodos. Danihelková, H., \& Malý, R. (2007). Člověk a jeho svět. Učebnice pro 3. ročník ZŠ. Olomouc: Prodos. Danihelková, H. (2007). Člověk a jeho svět. Učebnice pro 1. ročník ZŠ. Olomouc: Prodos.

Dvořáková, M., \& Stará, J. (2007). Prvouka: učebnice vzdělávací oblasti Člověk a jeho svět pro 1. ročník základní školy. Plzeň: Fraus.

Dvořáková, M., \& Stará, J. (2008). Prvouka: pracovní sešit pro 2. ročník základní školy. Plzeň: Fraus. Dvořáková, M., \& Stará, J. (2008). Prvouka: učebnice pro 2. ročník základní školy. Plzeň: Fraus.

Frýzová, I., \& Blažková, J., et al. (2008). Člověk a jeho svět: pracovní sešit pro 3. ročník základní školy. Brno: Didaktis.

Frýzová, I., \& Blažková, J., et al. (2008). Člověk a jeho svět: učebnice pro 3. ročník základní školy. Brno: Didaktis

Frýzová, I., Dvořák, L., \& Jůzlová, P. (2010). Příroda: Člověk a jeho svět pro 4. ročník základní školy. Plzeň: Fraus.

Frýzová, I., Dvořák, L., \& Jůzlová, P. (2010). Příroda: Pracovní sešit pro 4. ročník základní školy. Plzeň: Fraus.

Frýzová, I., Dvořák, L., \& Jůzlová, P. (2011). Příroda: Pracovní sešit pro 5. ročník základní školy. Plzeň: Fraus.

Frýzová, I., Dvořák, L., \& Jůzlová, P. (2011). Př́roda: Učebnice pro 5. ročník základní školy. Plzeň: Fraus.

Fukanová, J., \& Štiková, V. (2007). Já a můj svět: 1. ročník: pracovní učebnice prvouky pro 1. období RVP ZV. Brno: Nová škola.

Chramostová I., et al. (2011). Člověk a jeho svět: pracovní sešit pro 5. ročník základní školy. Brno: Didaktis.

Chramostová I., et al. (2011). Člověk a jeho svět: učebnice pro 5. ročník základní školy. Brno: Didaktis.

Jančová, M., \& Grigárková, M. (2008). Člověk a jeho zdraví: učebnice pro 4. a 5. ročník základní školy. Olomouc: Prodos.

Jančová, M. (2008). Člověk a jeho zdraví: pracovní sešit pro 4. a 5. ročník základní školy. Olomouc: Prodos.

Kopečková, S., et al. (2007). Člověk a jeho svět pro 1. ročník Ž̌. Brno: Didaktis.

Kholová, H., \& Bradáčková, L. (2009). Pracovní listy k učebnici Prvouka pro 3. ročník. II. díl. Všeň: Alter.

Kholová, H., \& Bradáčková, L. (2009). Prvouka pro 3. ročník ZŠ, II. díl. Všeň: Alter.

Kholová, H. (2009). Pracovní listy $k$ učebnici Život na zemi: rozmanitost př́rody, člověk a jeho zdraví. Př́rodověda pro 5. ročník. Všeň: Alter.

Kholová, H. (2009). Život na zemi: rozmanitost přírody, člověk a jeho zdraví. Př́ŕrodověda pro 5. ročník. Všeň: Alter.

Matyášek, J., Štiková, V., \& Trna, J. (2011). Př́rodověda pro 5. ročník, pracovní sešit: Člověk a jeho svět. Brno: Nová škola.

Matyášek, J., Štiková, V., \& Trna, J. (2011). Přírodověda pro 5. ročník: Člověk a jeho svět. Brno: Nová škola.

Rezutková, H. (2007). Cestička do školy I.: prvouka pro 1. ročník ZŠ. Všeň: Alter.

Rezutková, H. (2008). Cestička do školy II.: prvouka pro 1. ročník ZŠ. Všeň: Alter.

Rezutková H. (2010). Svět okolo nás: učebnice. Prvouka pro 2. ročník Ž̌. Všeň: Alter. 
Rezutková, H., Bradáčková, L., \& Bittmanová, K. (2010). Pracovní sešit ke světu okolo nás, I. díl. Všeň: Alter.

Stará, J., Dvořáková, M., \& Frýzová, I. (2009). Prvouka: pracovní sešit [s přílohou Přehled učiva] pro 3. ročník základní školy. Plzeň: Fraus.

Stará, J., Dvořáková, M., \& Frýzová, I. (2009). Prvouka: učebnice pro 3. ročník základní školy. Plzeň: Fraus.

Štiková, V. (2008). Já a můj svět: prvouka pro 2. ročník: pracovní sešit. Brno: Nová škola.

Štiková, V. (2008). Já a můj svět: prvouka pro 2. ročník: učebnice. Brno: Nová škola.

Štiková, V. (2008). Já a můj svět: prvouka pro 3. ročník: pracovní sešit. Brno: Nová škola.

Štiková, V. (2008). Já a můj svět: prvouka pro 3. ročník: učebnice. Brno: Nová škola.

\section{Autorka}

Mgr. Markéta Hrozová, Ph.D., Masarykova univerzita, Pedagogická fakulta, Katedra psychologie, Poříćí 31, 60300 Brno, email: marketa.hrozova@gmail.com

\section{Health education in primary school textbooks - results of a content analysis}

Abstract: The aim of the empirical study is to present results of content analysis of a didactic apparatus of the textbooks/workbooks of the subject natural science for elementary schools in terms of their focus on health education. The first part of the study presents the theoretical foundations of the research, which consisted in defining analytical categories arising from the holistic concept of health. The second part presents the objectives and methods of the research, a research sample consisting of five sets of current comprehensive natural science textbooks (38 textbooks / workbooks, 3136 research units) valid for primary education. The third part is devoted to the results of the analysis, which pointed out the significant differences in the presentation of the curriculum in health education. The results show disagreement with the holistic concept of health in its full representation, and a majority of biological context of health in the analysed textbooks. The holistic concept of health is mainly reflected in $2^{\text {nd }}$ grade textbooks. Then we pointed out the significant differences in the structure of the curriculum in each textbook set (for example, absence of health education topics in most $4^{\text {th }}$ grade textbooks), and its instability in the distribution of thematic units of the research sample. At the end of the study (fourth and fifth part), the results of the study, the possibilities and limits are discussed, and potential follow-up research is presented.

Keywords: health education, primary education, textbooks, holistic concept of health, content analysis, didactic apparatus of textbooks 